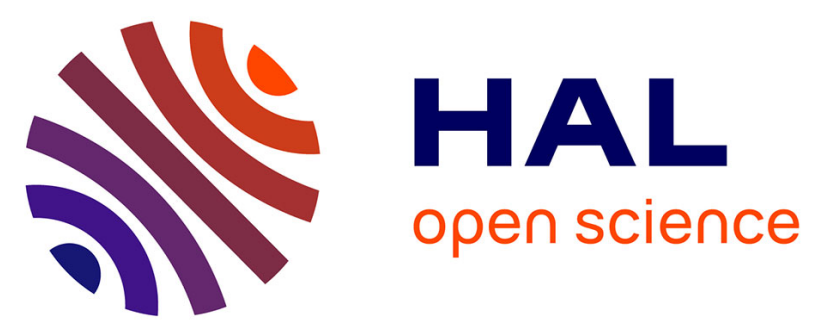

\title{
Synthesis, antibacterial evaluation, crystal structure and molecular interactions analysis of new 6-Bromo-2-chloro-3-butylquinazolin-4(3 H )-one
}

Oussama Ouerghi, Mohammed Geesi, Abdellah Kaiba, El Hassane Anouar, Abdul-Malek S. Al-Tamimi, Philippe Guionneau, Elmutasim O. Ibnouf, Rachid Azzallou, Md Afroz Bakht, Yassine Riadi

\section{To cite this version:}

Oussama Ouerghi, Mohammed Geesi, Abdellah Kaiba, El Hassane Anouar, Abdul-Malek S. AlTamimi, et al.. Synthesis, antibacterial evaluation, crystal structure and molecular interactions analysis of new 6-Bromo-2-chloro-3-butylquinazolin-4(3 H )-one. Journal of Molecular Structure, 2021, 1225, pp.129166. 10.1016/j.molstruc.2020.129166 . hal-02929647

\section{HAL Id: hal-02929647 https://hal.science/hal-02929647}

Submitted on 10 Sep 2020

HAL is a multi-disciplinary open access archive for the deposit and dissemination of scientific research documents, whether they are published or not. The documents may come from teaching and research institutions in France or abroad, or from public or private research centers.
L'archive ouverte pluridisciplinaire HAL, est destinée au dépôt et à la diffusion de documents scientifiques de niveau recherche, publiés ou non, émanant des établissements d'enseignement et de recherche français ou étrangers, des laboratoires publics ou privés. 


\title{
Synthesis, Antibacterial Evaluation, Crystal Structure and Molecular Interactions Analysis of New 6-Bromo-2-chloro-3-butylquinazolin-4(3H)-one
}

Oussama ouerghi, ${ }^{1,5}$ Mohammed H. Geesi, ${ }^{2}$ Abdellah Kaiba, ${ }^{1}$ El Hassane Anouar, ${ }^{2}$ Abdul-Malek S. Al-Tamimi, ${ }^{3}$ Philippe Guionneau, ${ }^{4}$ Elmutasim O.Ibnouf, ${ }^{6,7}$ Rachid Azzallou, ${ }^{8}$ Md Afroz Bakht, ${ }^{2}$ Yassine Riadi, ${ }^{3}{ }^{*}$

${ }^{1}$ Department of physic, College of science and humanities in Al-Kharj, Prince Sattam bin Abdulaziz University, Al-Kharj 11942, Saudi Arabia

${ }^{2}$ Department of Chemistry, College of science and humanities in Al-Kharj, Prince Sattam bin Abdulaziz University, Al-Kharj 11942, Saudi Arabia

${ }^{3}$ Department of Pharmaceutical Chemistry, College of Pharmacy, Prince Sattam bin Abdulaziz University, Al-Kharj 11942, Saudi Arabia

${ }^{4}$ CNRS, Univ. Bordeaux, Bordeaux INP, ICMCB, UMR 5026, 87 av. Dr A. Schweitzer, F-33600 Pessac (France)

${ }^{5}$ Department of Pharmaceutics, College of Pharmacy, Prince Sattam bin Abdulaziz University, Al-Kharj 11942, Saudi Arabia

${ }^{6}$ Université Tunis El Manar, Tunis 1068, Tunisia

${ }^{7}$ Department of Medical Microbiology, Faculty of Medical Laboratory Sciences, Omdurman Islamic University, Sudan.

${ }^{8}$ Department of Process engineering and Environment, Faculty of Science and Technology Mohammedia, University of Hassan II

-Casablanca, Morocco.

* Corresponding author. Tel.: +966 5374931 75; e-mail: y.riadi@psau.edu.sa/yassinriadi@yahoo.fr

\begin{abstract}
An efficient process was described to prepare a novel 6-bromo-2-chloro-3-butylquinazolin-4(3H)one. The targeted compound was synthesized from available chemicals and was also assessed for anti-bacterial activity. This new compound structure crystalizes in the triclinic system with $\mathrm{P}_{-1}$ space group. Its unit cell parameters are $(\mathrm{a}=4.91550(10) \AA, \mathrm{b}=11.4764(2) \AA, c=12.1670(3) \AA)$, volume (638.11(4) $\left.\AA^{3}\right), \alpha=110.079(8)^{\circ}, \beta=93.8130(10)^{\circ}, \gamma=95.4580(10)^{\circ}$ and $Z=2$. The crystal packing was stabilized by $\mathrm{C}=\mathrm{O} \ldots \mathrm{H}$ hydrogen bonds and $\mathrm{CH}_{3} \mathrm{CH}_{2} \mathrm{CH}_{2} \mathrm{CH}_{2} \mathrm{CHH} \ldots \mathrm{C} \pi$-stacking interaction and hydrogen $\pi-\pi$ stacking interactions. Hirshfeld surfaces and their associated twodimensional fingerprint plots were used to analyze the intermolecular interactions in the crystal structure. In addition, electrostatic surface potential (ESP) was generated using the density functional theory.
\end{abstract}

Keywords: 6-Bromo-2-chloro-3-butylquinazolin-4(3H)-one, Anti-bacterial, Crystal structure, Hirshfeld surface analysis.

\section{Introduction}


Quinazoline nuclei are diazotized heterocyclic compounds containing benzene and diazine cycles. These compounds are of great importance in the pharmacological and biological fields. Indeed, the quinazoline scaffold is present in the structure of many synthetic and natural compounds. The quinazoline derivatives show an important role in the preparation of versatile compounds that are biologically and pharmacologically active, such as: insecticides, herbicides [1], antifungals, [2] antibacterials, antivirals. [3] In fact, they are used as sedative agents [4], anthelmintics [5], potential radiosensitive agents [6], anti-tumor agents, [7-9] analgesic [10,11], anti-virus [12], anticytotoxin, anti-tuberculosis [13,14], antioxidant [15], antihypertension, anti-diabetes [16,17], etc. Pharmaceutical chemists prepared versatile types of quinazoline molecules that have shown variety of biological activities as efficient anti-allergic and anti-inflammatory drugs [18]. In addition, many examples of drugs were found such as proquazone [19], DQO-501 [20], and fluproquazone [21].

Therefore, and in continuation of on our research on the development of new routes to synthesize novel heterocyclic compounds [22-30]. Herein, we reported the preparation and the antibacterial activity assessement of novel quinazolinone molecule 6-bromo-2-chloro-3-butylquinazolin4(3H)-one (6) with good yield (Scheme 1). Crystallographic investigations of the synthesized compound $\mathbf{6}$ were performed at room temperature, along with description of its molecular interactions, electrostatic surface potential (ESP) and fingerprint plots.

\section{Synthesis}

To prepare the targeted derivative, we used the procedure described in reference [31]. First, a mixture of urea $(6 \mathrm{mmol})$ and 5-bromoanthranilic acid $(1 \mathrm{mmol})$ was grinded in a mortar, then heated at $200{ }^{\circ} \mathrm{C}$ till total transfer of the mixture to liquid. This mixture was then cooled and $\mathrm{NaOH}$ solution $(1 \mathrm{~N})$ was added, then the mixture was acidified using $\mathrm{HCl}$ solution $(1 \mathrm{~N})$, until the total precipitation of intermediate 4 . The mixture was filtered to obtain the compound 4 . Then, compound 4 (17.6 mmol) was chlorinated in presence of phosphoryl chloride $(176.4 \mathrm{mmol})$ and $\mathrm{N}, \mathrm{N}$-diisopropylethylamine $(26.4 \mathrm{mmol})$ and the reaction was refluxed for 6 hours. Afterword, the reaction was cooled and the excess of phosphoryl chloride was removed in vacuo. Then, the resulting mixture was dissolved in dichloromethane DCM $(25 \mathrm{~mL})$ and washed using water and dried over magnesium sulfate. Finally, solvent removed by evaporation to obtain the 6-bromo-2chloro-4(1H)-quinazolinone 4 . The intermediate 4 was reacted with an equimolar of 1 butylbromide $(1 \mathrm{mmol})$ in acetone $(10 \mathrm{~mL})$ and in presence of anhydrous potassium acetate $(1.5$ mmol) and under continuous stirring overnight. Reaction progression was controlled by thin layer 
chromatography $[\mathrm{TLC}])$. The resulting solid was extracted using dichoromethane (3 X $10 \mathrm{~mL}$ ), then the solvent was removed under vacuo and the obtained solid was purified through chromatography column (100\% DCM) to achieve the title derivative $\mathbf{6}$ as a yellow crystal (yield $81 \%)$.<smiles>Nc1ccc(Br)cc1C(=O)O</smiles>

1<smiles>NC(N)=O</smiles>

2

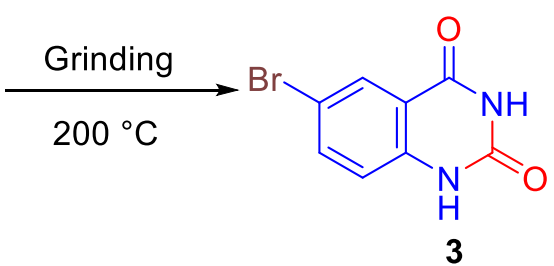

3

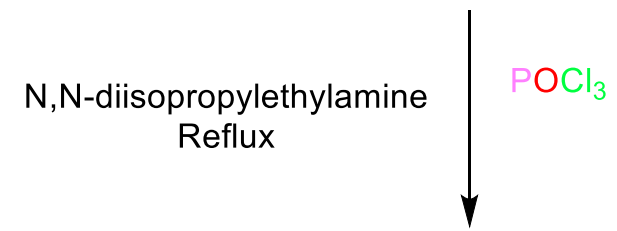

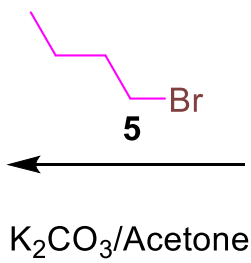

Reflux

6<smiles>O=c1nc(Cl)[nH]c2ccc(Br)cc12</smiles>

4

Scheme 1. Strategy of the preparation of 6-bromo-2-chloro-3-Butylquinazolin-4(3H)-one (6)

\section{Antibacterial activity}

Synthesized molecule $\mathbf{6}$ was tested for the antibacterial activity against two gram-positive bacteria (Bacillus subtilis and methicillin resistant Staphylococcus aureus [MRSA]) and two gram-negative bacteria, (Escherichia coli and Pseudomonas aeruginosa) using a standard method documented in reference [32] and also described in detail in a previous article by our group [25].

Results of the antibacterial activity of the derivative $\mathbf{6}$ were cited in Table 1. This compound $\mathbf{6}$ showed good activity against two bacterial strains only.

Table 1. Activity of the derivative $\mathbf{6}$ against bacterial strains.

\begin{tabular}{cccccc}
\cline { 3 - 6 } & & \multicolumn{4}{c}{ Bacterial Strains } \\
\cline { 3 - 6 } Derivative 6 & $\begin{array}{c}\text { Pa } \\
(\mu \mathrm{g} / \mathrm{ml})\end{array}$ & $-{ }^{\mathrm{b}}$ & 25 & 38.5 & Bc \\
\cline { 2 - 6 } & $\begin{array}{c}\mathrm{MBC} \\
(\mu \mathrm{g} / \mathrm{ml})\end{array}$ & $-{ }^{\mathrm{b}}$ & 18.75 & 25 & ${ }^{\mathrm{b}}$ \\
\hline
\end{tabular}




\begin{tabular}{|c|c|c|c|c|c|}
\hline & $\begin{array}{c}\text { Inhibition } \\
\text { zone in } \\
\mathrm{mm}(100 \\
\mu \mathrm{g} / \mathrm{ml})\end{array}$ & $-b$ & 20 & 16 & $-b$ \\
\hline Ciprofloxacin & $\begin{array}{c}\text { MIC } \\
(\mu \mathrm{g} / \mathrm{ml})\end{array}$ & 12.5 & 12.5 & 18.75 & 12.5 \\
\hline
\end{tabular}

${ }^{\mathrm{a}} \mathrm{MIC}$ : Minimum inhibitory concentration in $\mu \mathrm{g} / \mathrm{mL}$. MBC: Minimum bactericidal concentration

${ }^{\mathrm{b}}$ : No inhibition zone, no activity.

\section{Crystal structure}

Crystal data and structure refinement details are summarized in Table2. The collection data was carried out on Bruker Apex II diffractometer using a Molybdenum anticathode. A structural hypothesis was provided by SIR97 program [33]. The structure was solved by direct methods using SHELX97 program and all the atomic parameters are refined using a full-matrix least squares technique $\mathrm{F}^{2}$ based on squared structure factor $\mathrm{F}^{2}$ [34]. The non-hydrogen atoms were refined anisotropically but the hydrogen atoms were located theoretically. All the crystallography programs were used within the WINGX package [35]. The MERCURY program was used for Molecular graphics [36].

CCDC 2012234 contains crystallographic data for the present work. These data can be obtained free of charge via the following link: www.ccdc.cam.ac.uk/data_request/cif.

The structural resolution reveals that our compound crystallises in an triclinic system with a $\mathrm{P}_{-1}$ space group and unit parameters cell: $\mathrm{a}=4.91550(10) \AA, \mathrm{b}=11.4764(2) \AA, c=12.1670(3) \AA$ ), volume (638.11(4) $\left.\AA^{3}\right), \alpha=110.079(8)^{\circ}, \beta=93.8130(10)^{\circ}, \gamma=95.4580(10)^{\circ}$ and $Z=2$. The molecular structure of the title compound is illustrated in Figure 1.

The Atomic positions $(\mathrm{x}, \mathrm{y}, \mathrm{z})\left(\mathrm{x} 10^{4}\right)$ and equivalent isotropic displacement parameters $\mathrm{U}_{\mathrm{eq}}$ $\left(\AA^{2} \times 10^{3}\right)$ are summarized in Table 3 
Table 2: Crystallographic and structure refinement data

\begin{tabular}{|c|c|c|}
\hline Empirical formula & $\mathrm{C}_{12} \mathrm{H}_{12} \mathrm{BrCl} \mathrm{N} \mathrm{N}_{2} \mathrm{O}$ & \\
\hline Formula weight & 315.60 & \\
\hline Temperature & 293(2) K & \\
\hline Wavelength & $0.71073 \AA$ & \\
\hline Crystal system & Triclinic & \\
\hline Space group & $\mathrm{P}-1$ & \\
\hline \multirow[t]{3}{*}{ Unit cell dimensions } & $\mathrm{a}=4.91550(10) \AA$ & $\alpha=110.0790(10)^{\circ}$. \\
\hline & $\mathrm{b}=11.4764(2) \AA$ & $\beta=93.8130(10)^{\circ}$ \\
\hline & $\mathrm{c}=12.1670(3) \AA$ & $\gamma=95.4580(10)^{\circ}$ \\
\hline Volume & $638.11(2) \AA^{3}$ & \\
\hline $\mathrm{Z}$ & 2 & \\
\hline Density (calculated) & $1.643 \mathrm{Mg} / \mathrm{m}^{3}$ & \\
\hline Absorption coefficient & $3.415 \mathrm{~mm}^{-1}$ & \\
\hline $\mathrm{F}(000)$ & 316 & \\
\hline Crystal size & $0.160 \times 0.080 \times 0.080 \mathrm{~mm}^{3}$ & \\
\hline Theta range for data collection & 1.792 to $29.682^{\circ}$. & \\
\hline Index ranges & $-6<=\mathrm{h}<=6,-15<=\mathrm{k}<=15,-16<=\mathrm{l}<=16$ & \\
\hline Reflections collected & 25187 & \\
\hline Independent reflections & $3583[\mathrm{R}($ int $)=0.0340]$ & \\
\hline Completeness to theta $=25.242^{\circ}$ & $99.5 \%$ & \\
\hline Refinement method & Full-matrix least-squares on $\mathrm{F}^{2}$ & \\
\hline Data / restraints / parameters & $3583 / 0 / 155$ & \\
\hline Goodness-of-fit on F2 & 1.027 & \\
\hline Final $R$ indices $[I>2 \operatorname{sigma}(I)]$ & $\mathrm{R}_{1}=0.0378, \mathrm{wR}_{2}=0.0984$ & \\
\hline $\mathrm{R}$ indices (all data) & $\mathrm{R}_{1}=0.0629, \mathrm{wR}_{2}=0.1106$ & \\
\hline Largest diff. peak and hole & 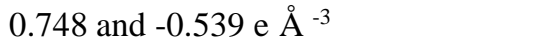 & \\
\hline
\end{tabular}




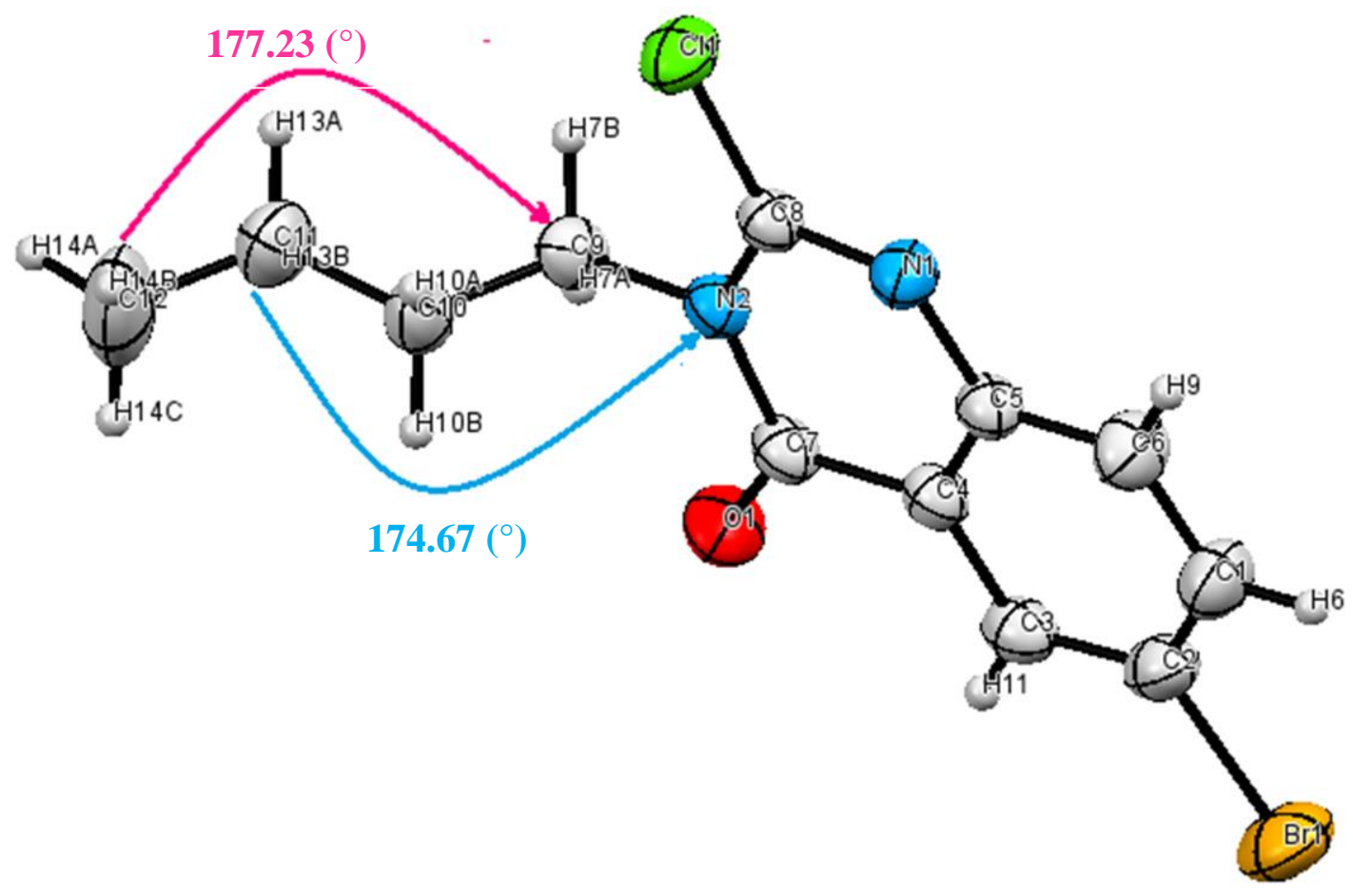

Figure 1: View along b axis of asymmetric unit cell of the titled compound.

\begin{tabular}{|l|l|l|l|}
\hline $\mathbf{x}$ & $\mathbf{y}$ & $\mathbf{z}$ & $\mathbf{U}_{\mathrm{eq}}$ \\
\hline
\end{tabular}


Table 3:

\begin{tabular}{|l|l|l|l|l|}
\hline $\mathrm{Br}(1)$ & $7652(1)$ & $9912(1)$ & $8590(1)$ & $65(1)$ \\
$\mathrm{Cl}(1)$ & $-5656(1)$ & $5642(1)$ & $3540(1)$ & $47(1)$ \\
$\mathrm{O}(1)$ & $1954(4)$ & $9061(2)$ & $4284(2)$ & $52(1)$ \\
$\mathrm{C}(4)$ & $1740(5)$ & $8174(2)$ & $5768(2)$ & $33(1)$ \\
$\mathrm{C}(8)$ & $-2892(5)$ & $6599(2)$ & $4343(2)$ & $32(1)$ \\
$\mathrm{N}(2)$ & $-1595(4)$ & $7544(2)$ & $4036(2)$ & $33(1)$ \\
$\mathrm{C}(2)$ & $4740(5)$ & $8808(2)$ & $7543(2)$ & $41(1)$ \\
$\mathrm{N}(1)$ & $-1844(4)$ & $6464(2)$ & $5341(2)$ & $37(1)$ \\
$\mathrm{C}(1)$ & $3404(6)$ & $7866(3)$ & $7850(2)$ & $48(1)$ \\
$\mathrm{C}(9)$ & $-2663(5)$ & $7740(2)$ & $2955(2)$ & $39(1)$ \\
$\mathrm{C}(5)$ & $378(5)$ & $7230(2)$ & $6075(2)$ & $34(1)$ \\
$\mathrm{C}(6)$ & $1252(6)$ & $7070(3)$ & $7124(2)$ & $45(1)$ \\
$\mathrm{C}(10)$ & $-1519(6)$ & $6951(3)$ & $1864(2)$ & $46(1)$ \\
$\mathrm{C}(3)$ & $3971(5)$ & $8957(2)$ & $6496(2)$ & $39(1)$ \\
$\mathrm{C}(7)$ & $805(5)$ & $8317(2)$ & $4657(2)$ & $36(1)$ \\
$\mathrm{C}(11)$ & $-2881(7)$ & $7100(3)$ & $773(3)$ & $57(1)$ \\
$\mathrm{C}(12)$ & $-1758(10)$ & $6394(5)$ & $-330(3)$ & $92(1)$ \\
\hline
\end{tabular}

Atomic positions $\left(\mathrm{x} 10^{4}\right)$ and equivalent isotropic displacement parameter $\mathrm{U}(\mathrm{eq}) \AA^{2} \mathrm{x} 10^{3}$ ) for $\mathrm{C}_{12} \mathrm{H}_{12} \mathrm{Br} \mathrm{Cl} \mathrm{N} \mathrm{N}_{2} \mathrm{O}$

The cohesion is ensured by hydrogen bonds, $\pi$ stacking interaction and $\pi-\pi$ stacking interaction between rings. The hydrogen bonds distances $\mathrm{C}=\mathrm{O} \ldots \mathrm{H}$ and $\mathrm{CH}_{3} \mathrm{CH}_{2} \mathrm{CH}_{2} \mathrm{CHH} \ldots \mathrm{C} \pi$ stacking 
(Figure. 2) are respectively $2.390 \AA$ and $2.878 \AA$. The $\pi$ - $\pi$ stacking interactions between rings of molecules are presented in Figure. 3, the centroid - centroid distances between two neighboring molecules is about $4.915 \AA$. The distance between carbon atoms $\mathrm{C}-\mathrm{C}$ is between 1.368(4) and 1.516(4) $\AA$. The C-N distance is between 1.350(3) $\AA$ and 1.481(3) $\AA$. The $\mathrm{C}$-Br distance is about 1.892(2) $\AA$. and $\AA$ Finally, $\mathrm{C}=\mathrm{O}$ distance is approximately $1.210(3) \AA$. The torsion angle value C12-C11-C10-C9 and C11-C10-C9-N2 is about $177.23\left(^{\circ}\right)$ and $174.77\left(^{\circ}\right)$ respectively, this shows that the $\mathrm{CH}_{3}-\mathrm{CH}_{2}-\mathrm{CH}_{2}-\mathrm{CH}_{2}$ - is slightly twisted (Figure1).

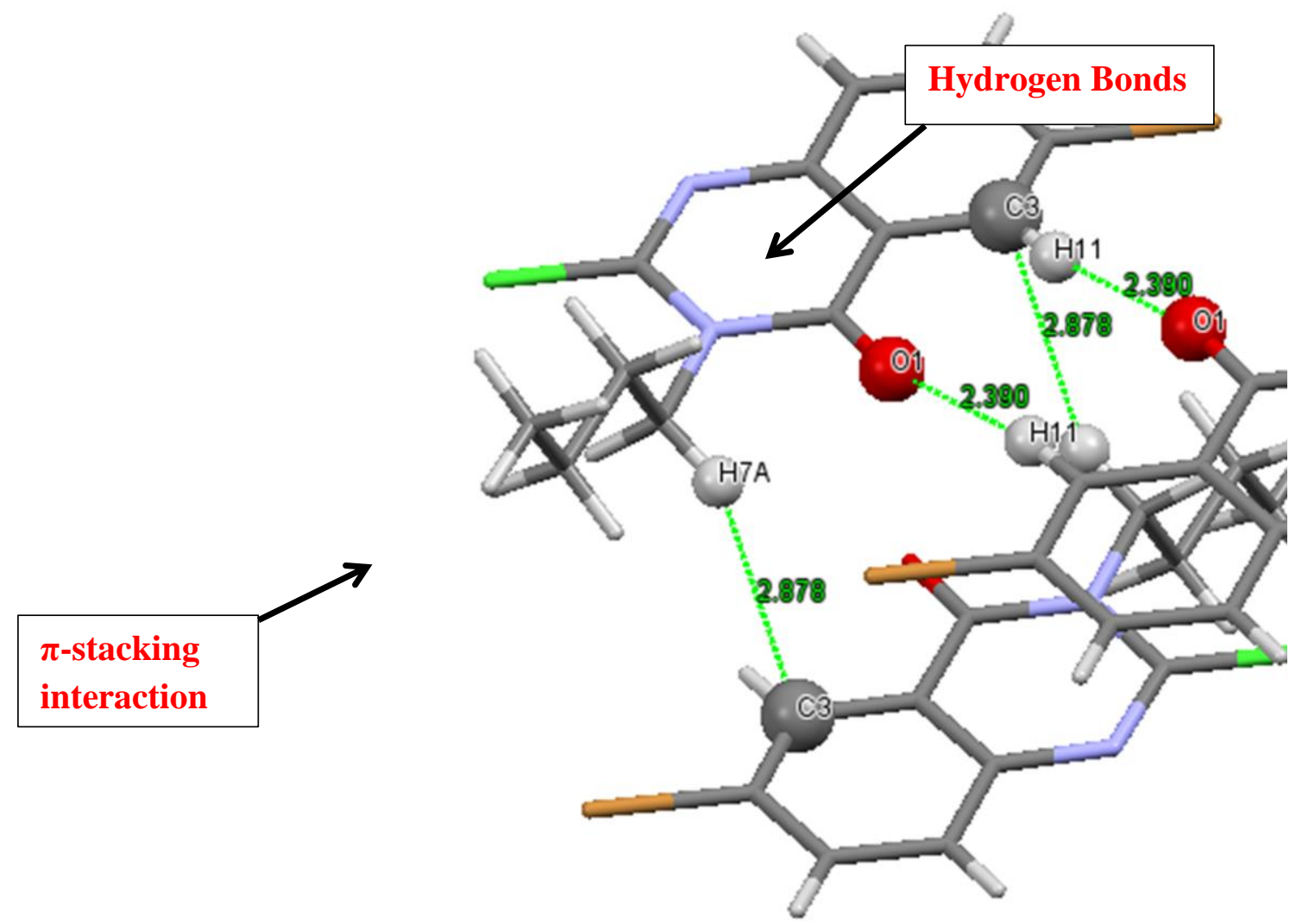

Figure 2: View showing the connection between the molecules by $\mathrm{C}=\mathrm{O} \ldots \mathrm{H}$ hydrogen bonds and $\mathrm{CH}_{3} \mathrm{CH}_{2} \mathrm{CH}_{2} \mathrm{CHH}$...C $\pi$-stacking interaction (dashed lines). 


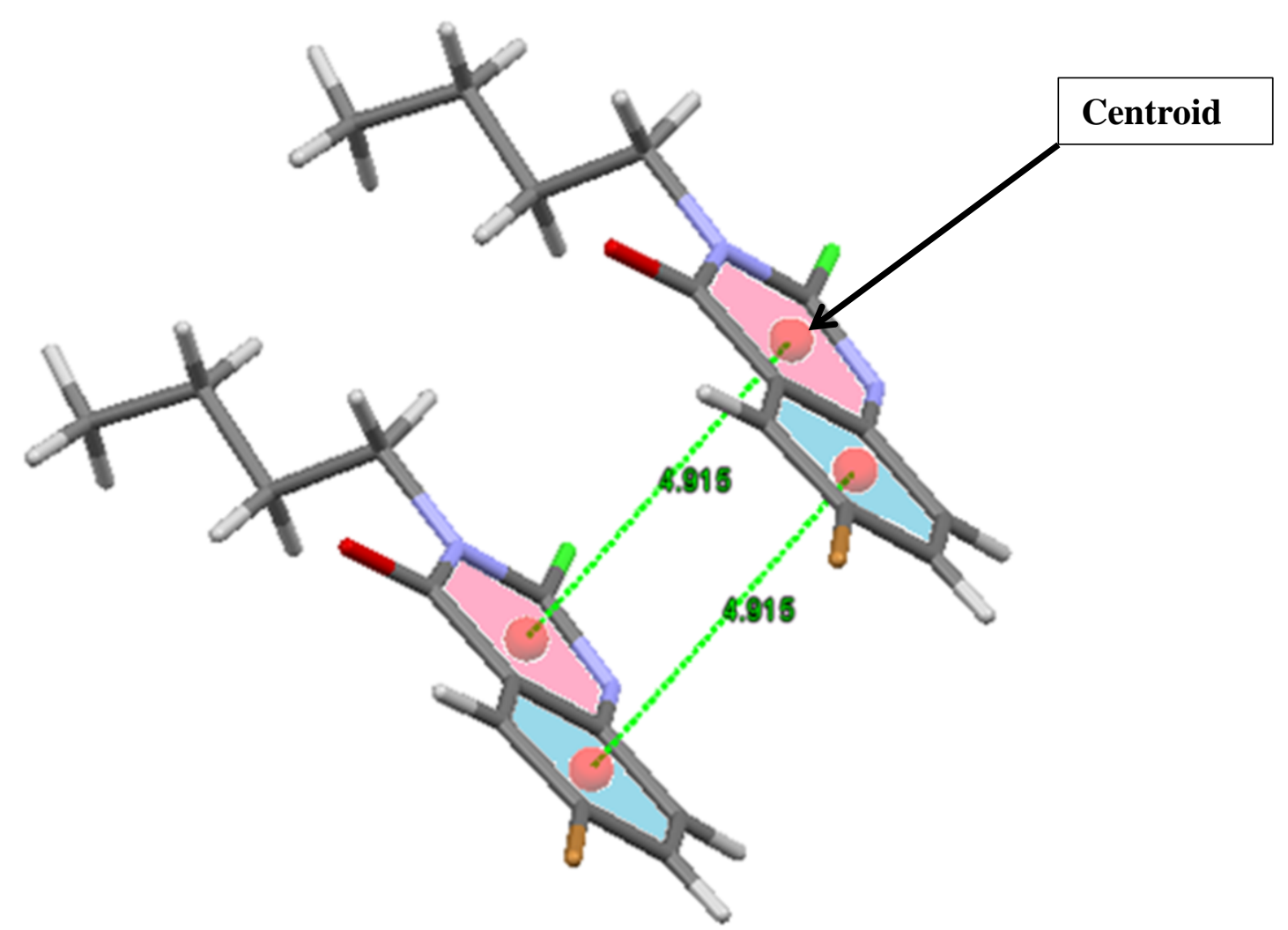

Figure 3: View showing the crystal cohesion by $\pi-\pi$ stacking interactions between two neighboring molecules

The crystal structure is built via hydrogen bonds and $\pi-\pi$ stacking interactions between neighboring molecules. These intermolecular interactions between molecules allows the crystal packing build up(Figure 4). Indeed, each molecule communicates with two other neighboring molecules through oxygen atom, butyl group and benzene via hydrogen bonds, $\pi$-stacking and trough $\pi-\pi$ stacking interactions.

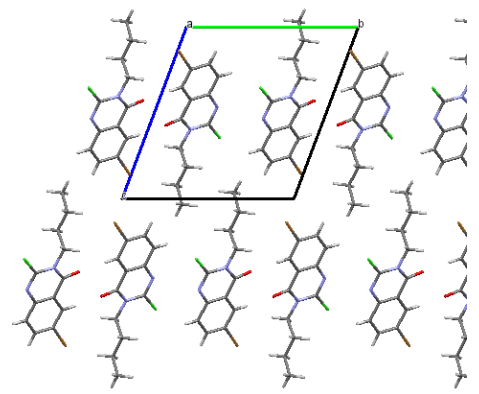

(a)

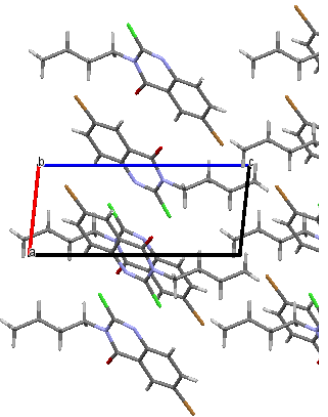

(b)

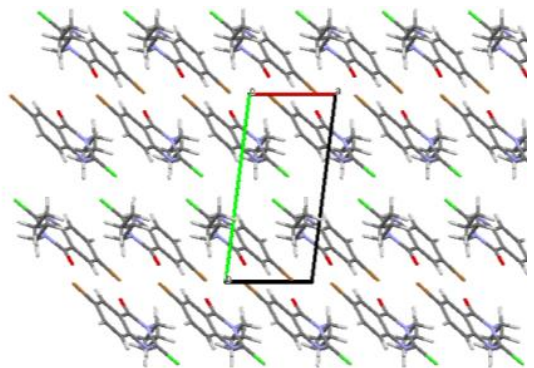

(c) 
Figure 4: Packing of molecules in the crystal . $a$ - Projection along a axis, b- Projection along b axis, c- Projection along c axis.

\section{Computational details}

\section{4-1 Hirshfeld surface calculations}

Hirshfeld surface and fingerprint plot of the $\mathrm{C}_{12} \mathrm{H}_{12} \mathrm{Br} \mathrm{Cl} \mathrm{N} 2 \mathrm{O}$ were performed using Crystal Explorer 3.0 package [37].The $\mathrm{d}_{\text {norm }}$ plots range delimited by -0.2759 a.u for blue color and 1.6303 a.u for red one. The red spots on the Hirshfeld surface indicate the interactions that involved intermolecular hydrogen bonding between $\mathrm{C}_{12} \mathrm{H}_{12} \mathrm{Br} \mathrm{Cl} \mathrm{N} \mathrm{N}_{2} \mathrm{O}$ units. 2D-fingerprint plots were displayed by using the expanded 0.6-2.8 $\AA$. The electrostatic surface potential (ESP) of $\mathrm{C}_{12} \mathrm{H}_{12} \mathrm{Br}$ $\mathrm{Cl} \mathrm{N}_{2} \mathrm{O}$ is determined at the DFT-B3LYP/6-311+G(d,p) level of theory using the Gaussian 16 package [38].

\section{4-2 Hirshfeld surface analysis}

Hirshfeld surface of $\mathrm{C}_{12} \mathrm{H}_{12} \mathrm{Br} \mathrm{Cl} \mathrm{N} 2 \mathrm{O}$ mapped over the normalized contact distance $\mathrm{d}_{\text {norm }}$ is shown in Figure 5 (left). The red spots on the Hirshfeld surface indicate the formation of two strong hydrogen bonding of $2.241 \AA$ between the units of $\mathrm{C}_{12} \mathrm{H}_{12} \mathrm{BrClN}_{2} \mathrm{O}$ (Figure 5, left). The first intermolecular hydrogen bond is established between the lone pair of the oxygen atom of the carbonyl group of quinazoline of the basic unit and the hydrogen atom of the aromatic ring at C5 position of the closest unit (Figure 5, left). The second hydrogen bond is formed between the hydrogen atom of the aromatic ring at $\mathrm{C} 5$ position of the basic unit and the lone pair of the oxygen atom of the carbonyl group of quinazoline of the closest unit (Figure 5, left). The Hirshfeld surface analysis reveals that the intermolecular interactions between are $\pi$-stacking interactions, and the units are stacked in head-to-tail one above the other. The intermolecular distance between the stacked units is of $3.84 \mathrm{~A}$ (Figure 5, left).
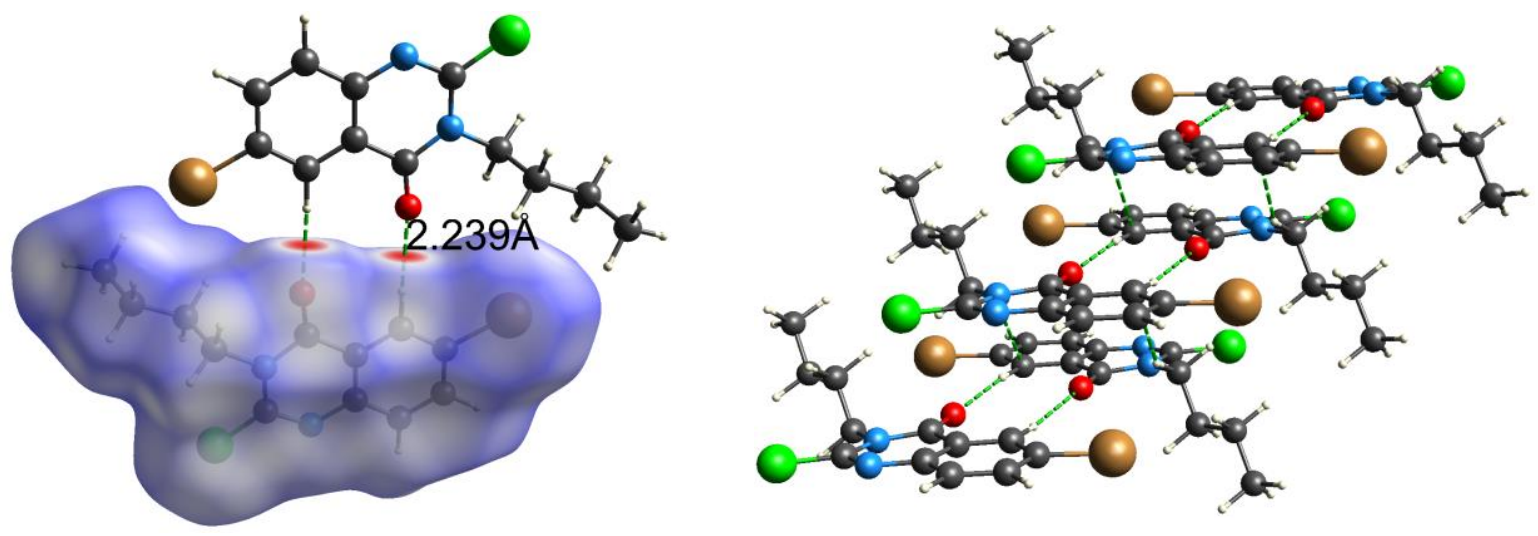
Figure 5: $d_{\text {norm }}$ mapped on the Hirshfeld surface for visualizing intermolecular interactions of the title compound.

The electrostatic surface potentials (ESP) of $\mathrm{C}_{12} \mathrm{H}_{12} \mathrm{BrClN}_{2} \mathrm{O}$ is shown in Figure 6. In ESP, the red color is attributed to the negative region, which corresponds to hydrogen bond acceptors. However, the blue color indicates the positive region, which corresponds to hydrogen bond donors. As can be seen from Figure 6, the lone pair of oxygen atom of carbonyl moiety of quinazoline is a hydrogen bond acceptor. This result is in accordance with the Hirshfeld surface analysis, which show the formation of a strong intermolecular hydrogen bond between the one pair of oxygen atom of carbonyl moiety of quinazoline and the hydrogen atom of $\mathrm{CH}$ of the aromatic ring (Figure 5).

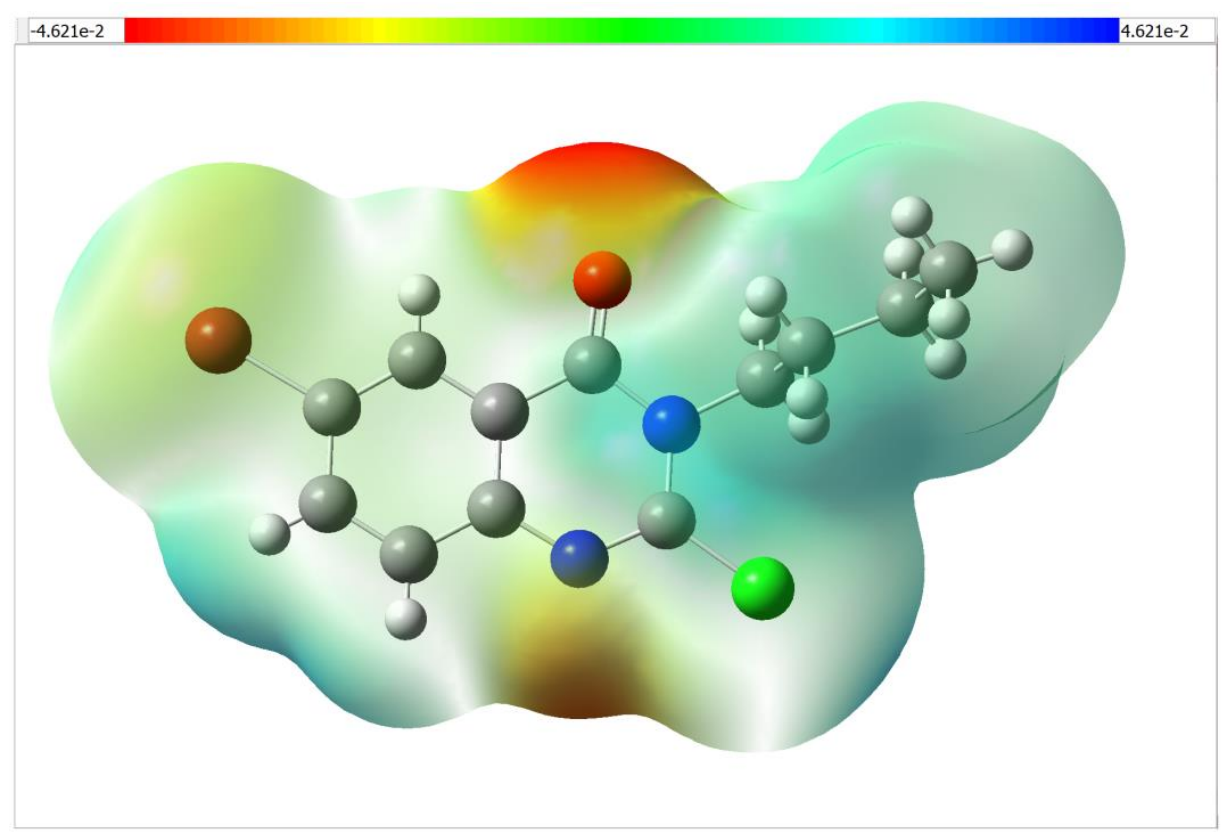

Figure 6: Electrostatic surface potential of $\mathrm{C}_{12} \mathrm{H}_{12} \mathrm{BrClN}_{2} \mathrm{O}$ obtained at the $\mathrm{B} 3 \mathrm{LYP} / 6-311+\mathrm{G}(\mathrm{d}, \mathrm{p})$ level of theory.

The 2D fingerprint plots for the most intercontacts between the $\mathrm{C}_{12} \mathrm{H}_{12} \mathrm{BrClN}_{2} \mathrm{O}$ units are shown in Figure 7 and the ratio of their contributions are summarized in Table 4. The highest inter atomic contact contribution were found between hydrogen atoms $\mathrm{H}^{\cdots} \mathrm{H}$, about $39.6 \%$ (Figure 4), followed by $\mathrm{Br} . . \mathrm{H} / \mathrm{H} \ldots \mathrm{Br}, \mathrm{Cl} \ldots \mathrm{H} / \mathrm{H} \ldots \mathrm{Cl}$ and $\mathrm{O} \ldots \mathrm{H} / \mathrm{H} \ldots \mathrm{O}$ about $13.5,8.0$ and $7.4 \%$, respectively. 

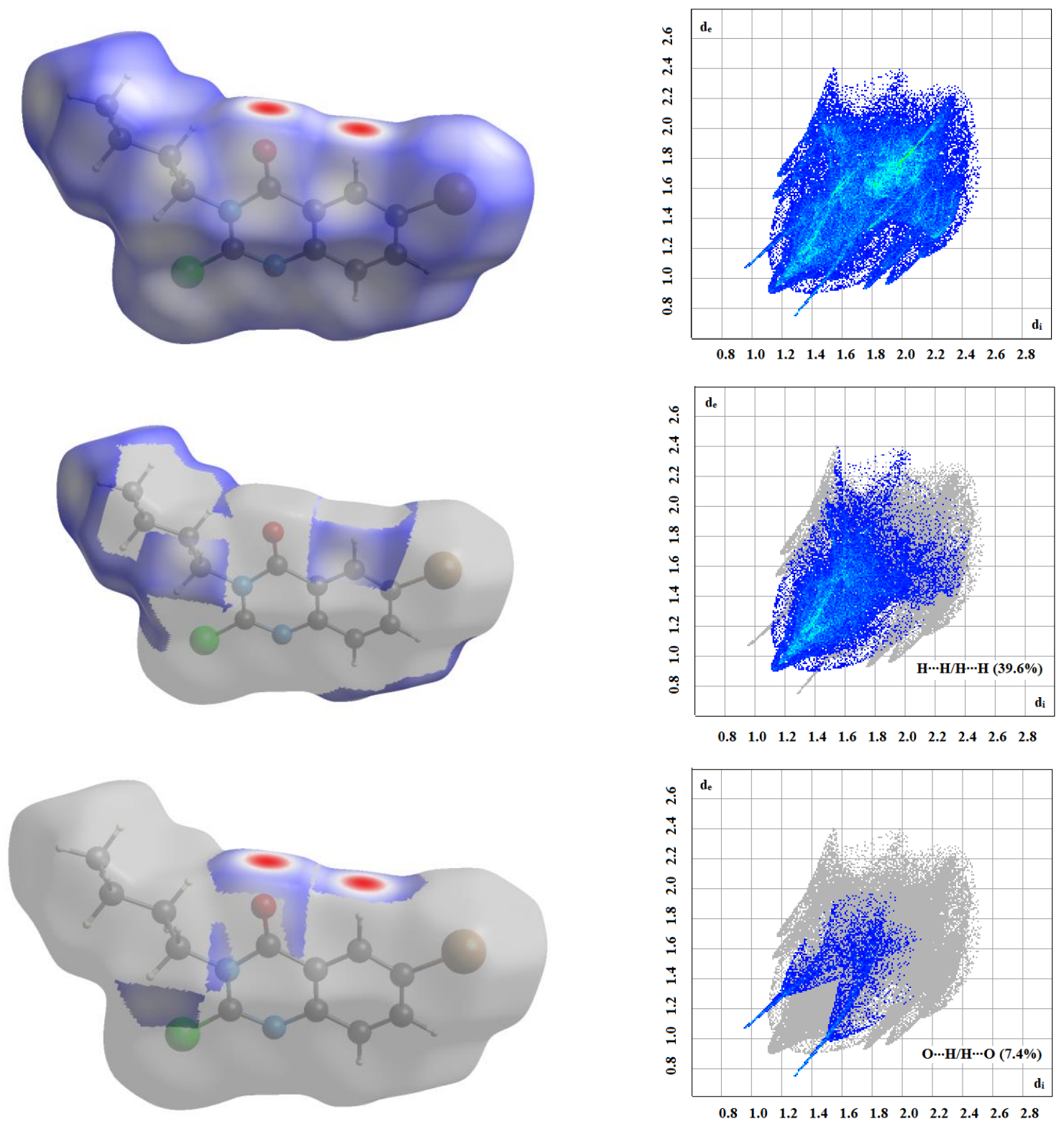

Figure 7: The two-dimensional fingerprint plots for the title compound showing all (up), $\mathrm{Br}{ }^{\cdots} \mathrm{H} / \mathrm{H} \cdots \mathrm{Br}$ (middle) and $\mathrm{O} \cdots \mathrm{H} / \mathrm{H}^{\cdots} \cdot \mathrm{H}$ (bottom) closest intercontacts.

Table 4: Summary of the major closest contacts and their percentage contributions to the Hirshfeld surface.

\begin{tabular}{lc}
\hline Type of contact & Contribution (\%) \\
\hline $\mathrm{H} \cdots \mathrm{H}$ & 39.6 \\
$\mathrm{Br}{ }^{\cdots} \mathrm{H} / \mathrm{H}{ }^{\cdots} \mathrm{Br}$ & 13.5 \\
$\mathrm{Cl} \cdots \mathrm{H} / \mathrm{H}^{\cdots} \mathrm{Cl}$ & 8.0 \\
\hline
\end{tabular}




\begin{tabular}{lc}
\hline $\mathrm{O} \cdots \mathrm{H} / \mathrm{H} \cdots \mathrm{O}$ & 7.4 \\
$\mathrm{C} \cdots \mathrm{H} / \mathrm{H} \cdots \mathrm{C}$ & 6 \\
\hline
\end{tabular}

\section{Conclusion}

In summary, we have described the preparation of a new 6-bromo-2-chloro-3-buylquinazolin4(3H)-one (6). Its anti - bacterial efficacy has been evaluated against different bacterial strains. The single crystal XRD structural studies of the 6-bromo-2-chloro-3-butylquinazolin-4(3H)-one was performed. The compound crystallized in monoclinic crystal system with P-1 space group. It exhibited hydrogen bond interaction $\mathrm{C}=\mathrm{O} \ldots \mathrm{H}, \mathrm{CH}_{3} \mathrm{CH}_{2} \mathrm{CH}_{2} \mathrm{CHH} \ldots \mathrm{C} \pi$-stacking interactions and slight $\pi-\pi$ stacking interactions between rings of the molecule that assure the connection between molecules and stabilize the crystal. Moreover, the contribution of these interactions was also analysed by visualizing Hirshfeld surface. In addition, the electrostatic surface potential (ESP) was obtained using the DFT method.

\section{Acknowledgments}

The authors would like to thank the Deanship of Scientific Research at Prince Sattam Bin Abdulaziz University for providing financial support for this project (grant no. 2019/03/11064).

\section{References:}

[1].S. Raw, C. Wilfred, R. Taylor, J. K. Org, Biomol. Chem, 2004, 2, 788.

[2]. G. Cheeseman, R. Cookson, in: A. Weissberger, E.C. Taylor, The Chemisty of Heterocyclic Compounds, 35, John Wiley and Sons, New York, 1979, 1.

[3].A. Porter, in: A. Katrizky, C. Rees, Comprehensive Heterocyclic Chemistry, 3, Pergamon Press, New York, 1984,195.

[4]. Opitz, W., Jacobi, H., Pelster, B.: Eur. Patent Ger. Offen. De., 220,438(Cl. C07D487/04), 01 Dec1983, Appl. 29 May 1982.

[5].Pandey, M.P.: Acta cien, Indica, [Ser]. Chem., 1984, 10, 178.

[6].Kalinowska, T.: Acta Pol. Pharm., 1985, 42, 212.

[7].Baguley, B.C.: DNA intercalating antitumor agents, Anti-Cancer Drug Des., 1991, 6, 1- 35.

[8].Brana, W.F., Castello, J.M., Keilhauter, G., Machuca, A., Martin, Y., Redondo,C., Schlick, E., Walker, N.: Benzimidazo[1,2-c]quinazolines: a new class of antitumor compounds, AntiCancer Drug Des. 1994, 9, 527-538.

[9].Werbet, L.M., Angelo, M., Fry, D.W., Worth, D.F.: Basically substituted ellipticine analogues as potential antitumor agents, J. Med. Chem, 1986, 29, 1321-1322.

[10]. Alagarsamy V, Solomon VR, Dhanabal K: Synthesis and pharmacological evaluation of some 3-phenyl-2-substituted-3H -quinazolin-4-one asanalgesic, antiinflammatory agents. Bioorg Med Chem 2007, 15:235-241.

[11]. Jatav V, Kashaw S, Mishra P: Synthesis and antimicrobial activity of some new 3-[5-(4substituted)phenyl-1,3,4-oxadiazole-2yl]-2-styrylquinazoline-4(3H)-ones. Med Chem Res 2008, 17:205-211.

[12]. Li H, Huang R, Qiu D, Yang Z, Liu X, Ma J, Ma Z: Synthesis and bioactivity of 4quinazoline oxime ethers. Prog Nat Sci 1998, 8:359-365. 
[13]. Chandrika PM, Yakaiah T, Narsaiah B, Sridhar V, Venugopal G, Rao JV, Kumar KP,Murthy USN, Rao ARR: Synthesis leading to novel 2,4,6-trisubstitutedquinazoline derivatives, their antibacterial and cytotoxic activity againstTHP-1, HL-60 and A375 cell lines. Indian J Chem 2009, 48B:840-847.

[14]. Nandy P, Vishalakshi MT, Bhat AR: Synthesis and antitubercular activity of Mannich bases of 2-methyl-3H-quinazolin-4-ones. Indian J HeterocyclChem 2006, 15:293-294.

[15]. Saravanan G, Alagarsamy V, Prakash CR: Synthesis and evaluation of antioxidant activities of novel quinazoline derivatives. Int J Pharm Pharm Sci 2010, 2:83-86.

[16]. Hess HJ, Cronin TH, Scriabine A: Antihypertensive 2-amino-4(3H)-quinazolinones. J Med Chem 1968, 11:130-136.

[17]. Malamas MS, Millen J: Quinazolineacetic acids and related analogs as aldosereductase inhibitors. J Med Chem 1991, 34:1492-1503.

[18]. S. Johne, Progress in Drug Research, 26, 259-341 (1982).

[19]. R. V. Coombs, R. P. Danna, M. Denzer, G. E. Hardtmann, B. Huegi, G. Koletar, J.Koletar, H. Ott, Jukniewciz, J. W. Perrine, E. J. Takesue and J. H. Trapold, JMed.Chem., $16,1237-45$ (1973).

[20]. M. Gilberto, S. D. Silva, C. M. R Sant'Anna and E. J Barreiro, Bioorg. Med. Chem.,12, 3159-3166 (2004).

[21]. J. W. Perrine, W. J. Houlihan and E. I. Takesue, Arzneim. Forsch. / Drug Res., 34,879885 (1984).

[22]. Y. Riadi, S. Massip, J.-M. Leger, C. Jarry, S. Lazar, and G. Guillaumet, 'Convenient synthesis of 2, 4-disubstituted pyrido $[2,3-d]$ pyrimidines via regioselective palladiumcatalyzed reactions', Tetrahedron, vol. 68, no. 25, pp. 5018-5024, 2012.

[23]. M. H. Geesi, M. E. Moustapha, M. A. Bakht, Y. Riadi, 'Ultrasound-accelerated green synthesis of new quinolin-2-thione derivatives and antimicrobial evaluation against Escherichia coli and Staphylococcus aureus', Sustainable Chemistry and Pharmacy, vol. 15, pp. 100195, 2020.

[24]. Y. Riadi, 'UV Light Mediated Palladium-Catalyzed Synthesis of 2-Substituedpyrido[2,3d]pyrimidines', Polycyclic Aromatic Compounds, pp. 1-6, 2019.

[25]. M. H.Geesi, Y. Riadi, A. Kaiba, E. Anouar, O. Ouerghi, E. O.Ibnouf, P. Guionneaug, Journal of Molecular Structure, 1215, p. 128265, 2020.

[26]. Y. Riadi, 'UV Light-mediated regioselective methylsulfanyl discrimination via Pdcatalyzed cross-coupling reactions of 2,4-dimethylsulfanylpyrido[2,3-d]pyrimidines', Journal of Sulfur Chemistry, vol. 40, no. 4, pp. 351-360, 2019.

[27]. Y. Riadi, S. Lazar, G. Guillaumet, 'Regioselective palladium-catalyzed Suzuki-Miyaura coupling reaction of 2,4,6-trihalogenopyrido[2,3-d]pyrimidines', Comptes Rendus Chimie, vol. 22, no. 4, pp. 294-298, 2019.

[28]. Y. Riadi, M. Geesi, O. Dehbi, M. A. Bakht, M. Alshammari, and M.-C. ViaudMassuarde, 'Novel animal-bone-meal-supported palladium as a green and efficient catalyst for Suzuki coupling reaction in water, under sunlight', Green Chemistry Letters and Reviews, vol. 10, no. 2, pp. 101-106, 2017. 
[29]. Y. Riadi and M. Geesi, 'Photochemical route for the synthesis of novel 2monosubstituted pyrido [2, 3-d] pyrimidines by palladium-catalyzed cross-coupling reactions', Chemical Papers, vol. 72, no. 3, pp. 697-701, 2018.

[30]. M. H. Geesi, 'Synthesis, antibacterial evaluation, Crystal Structure and Hirshfeld surface analysis of a new 2-benzylsulfanyl-3-(4-fluoro-phenyl)-6-methyl-3H-quinazolin-4-one', Journal of Molecular Structure, p. 127894, 2020.

[31]. T. Chihiro, O. Masataka, N. Hiromi, T. Yoshiji, Palladium(0)-Catalyzed CarbonHydrogen Bond Functionalization for the Synthesis of Indoloquinazolinones, Advanced Synthesis \& Catalysis, 356(7), 1533-1538; 2014.

[32]. E. H. Simpson, 'Prevalence of penicillin-resistant Streptococcus pneumoniaeConnecticut, 1992-1993, 1994.

[33]. A. Altomare, M.C. Burla, M. Camalli, G.L. Cascarano, C. Giacovazzo, A. Guagliardi, A.G. Moliterni, G. Polidori, R. Spagna, SIR97: a new tool for crystal structure determination and refinement, Journal of Applied Crystallography 32(1) (1999) 115-119.

[34]. G.M. Sheldrick, A short history of SHELX, Acta Crystallographica Section A: Foundations of Crystallography 64(1) (2008) 112-122.

[35]. L.J. Farrugia, WinGX suite for small-molecule single-crystal crystallography, Journal of Applied Crystallography 32(4) (1999) 837-838.

[36]. C.F. Macrae, I.J. Bruno, J.A. Chisholm, P.R. Edgington, P. McCabe, E. Pidcock, L. Rodriguez-Monge, R. Taylor, J. Streek, P.A. Wood, Mercury CSD 2.0-new features for the visualization and investigation of crystal structures, Journal of Applied Crystallography 41(2) (2008) 466-470.

[37]. M. Turner, J. McKinnon, S. Wolff, D. Grimwood, P. Spackman, D. Jayatilaka, M. Spackman, CrystalExplorer17, University of Western Australia, 2017.

[38]. M.J. Frisch, G.W. Trucks, H.B. Schlegel, G.E. Scuseria, M.A. Robb, J.R. Cheeseman, G. Scalmani, V. Barone, G.A. Petersson, H. Nakatsuji, X. Li, M. Caricato, A.V. Marenich, J. Bloino, B.G. Janesko, R. Gomperts, B. Mennucci, H.P. Hratchian, J.V. Ortiz, A.F. Izmaylov, J.L. Sonnenberg, Williams, F. Ding, F. Lipparini, F. Egidi, J. Goings, B. Peng, A. Petrone, T. Henderson, D. Ranasinghe, V.G. Zakrzewski, J. Gao, N. Rega, G. Zheng, W. Liang, M. Hada, M. Ehara, K. Toyota, R. Fukuda, J. Hasegawa, M. Ishida, T. Nakajima, Y. Honda, O. Kitao, H. Nakai, T. Vreven, K. Throssell, J.A. Montgomery Jr., J.E. Peralta, F. Ogliaro, M.J. Bearpark, J.J. Heyd, E.N. Brothers, K.N. Kudin, V.N. Staroverov, T.A. Keith, R. Kobayashi, J. Normand, K. Raghavachari, A.P. Rendell, J.C. Burant, S.S. Iyengar, J. Tomasi, M. Cossi, J.M. Millam, M. Klene, C. Adamo, R. Cammi, J.W. Ochterski, R.L. Martin, K. Morokuma, O. Farkas, J.B. Foresman, D.J. Fox, Gaussian 16 Rev. C.01, Wallingford, CT, 2016. 